\title{
Financing Smallholder Rice Farmers: A Field-Based Evidence Review of Anchor Borrowers' Programme (ABP) Model in Nigeria
}

\author{
Uchenna Obih, Lloyd Baiyegunhi \\ University of KwaZulu-Natal, Pietermaritzburg, South Africa \\ obih_uchenna@yahoo.com, Baiyegunhil@ukzn.ac.za
}

\begin{abstract}
Nigeria's spending of US\$2billion annually on rice importation has been considered a major source of foreign exchange drain and a threat to domestic rice industry. One of the major reasons adduced for this high import bills is the persistent demand-supply gap arising from the country's inability to increase domestic output of paddy rice to optimize the total capacity of several integrated rice mills established across the country in the last 15 years. In 2015, the government launched the Anchor Borrowers' Programme (ABP) to make cheap funds accessible to smallholder farmers (SHFs) who produce more than $85 \%$ of total farm output in Nigeria. ABP is designed to encourage banks to lend to SHFs to boost paddy rice production. This paper presents the field experiences of SHFs, banks and rice millers who participated in the programme in 2016/2017. This paper concludes that ABP is a laudable programme that can contribute in achieving the food security objective of the government. The key challenges found to be threatening the success and sustainability of ABP included delays in timely disbursement of funds by deposit money banks (DMBs), inadequate personnel and institutional framework, side-selling of harvested paddy rice by SHFs, State government undue involvement in the $\mathrm{ABP}$, and poor rural infrastructure. Policy recommendations to strengthen the ABP model for improved impact were discussed.
\end{abstract}

Keywords: Anchor Borrowers' Programme, Smallholder farmers, Anchor, Central Bank of Nigeria, Deposit Money Banks, Nigeria

\section{Introduction}

Rice (oryza sativa) is a major staple food in Nigeria; its consumption has no cultural, religious, ethnic or geographical boundary (Isa et al., 2013). According to Johnson et al. (2013), the commodity ranks first among all staple food items in terms of expenditures and second only to cassava in terms of quantity consumed. Considering the country's large population of over 170 million people, high per capita annual consumption of $40 \mathrm{~kg}$ (USDA, 2016) and general acceptability of rice, Nigeria is the largest consumer of rice in Africa. The country's estimated average annual demand for milled rice is 5.2 million tons, while the average national production of paddy is 3.8 million tons. Given the country's rice processing capacity and average recovery ratio of 62\% (Ogunfowora, 2007), an annual average of 2.4 million tons of milled rice is produced domestically (USDA, 2016). This gives an average annual demand-supply gap of 1.9million tons of milled rice. To bridge this gap, milled rice worth US $\$ 2$ billion is being imported annually into the country (Ayanwale and Amusan, 2012) and this has made Nigeria the largest importer of rice in Africa (FAO, 2012).

Nigeria's dependency on rice imports is a huge drain on the country's foreign currency reserves, increases her vulnerability to global price shocks, threatens the growth of domestic rice industry and raises overall concerns about the country's food insecurity. Consequently, the country, like many other countries, has adopted the import substitution strategy by introducing various initiatives and programmes designed to promote domestic rice production to achieve self-sufficiency through import restrictions and investments to improve product output and quality. The total annual demand for rice in Nigeria has been consistently declining since 2013 (Table 1). This is largely due to declining consumer purchasing power and rising market prices; both caused by current price inflation and currency devaluation. Output of milled rice has remained stable at an average of 2.7 million tons per annum while import has declined mainly due to stringent import restriction policy measures imposed by the government and scarcity of foreign exchange. Despite declining consumption and imports, the demand-supply gap has remained stable at an average of 2.5 million tons per annum. Opeyemi et al. (2015) found that non-availability in the market all year round is one of the major factors that affect the demand for locally milled rice in Nigeria. Thus, the only way Nigeria can attain selfsufficiency in rice production is to achieve average paddy output of at least 8.4million tons per annum, which is more than twice the current average annual paddy production in Nigeria. This requires the expansion of current cultivable land of 2.3 million hectares and an increasing current average yield of 1.56 tons per hectare (USDA, 2016). 
Table 1: Trends of Nigeria's Milled Rice Demand, Supply and Import ('000 Mt) 2000 - 2016

\begin{tabular}{llllll}
\hline Year & Demand & Supply (paddy) & Supply (milled) & Import & Demand-Supply Gap \\
\hline 2000 & 3029 & 3298 & 1979 & 1250 & 1050 \\
2001 & 3051 & 2752 & 1651 & 1906 & 1400 \\
2002 & 3307 & 2928 & 1757 & 1897 & 1550 \\
2003 & 3670 & 3117 & 1870 & 1448 & 1800 \\
2004 & 3750 & 3333 & 2000 & 1369 & 1750 \\
2005 & 3800 & 3567 & 2140 & 1650 & 1660 \\
2006 & 4040 & 4041 & 2546 & 1500 & 1494 \\
2007 & 4100 & 3187 & 2008 & 1800 & 2092 \\
2008 & 4220 & 4178 & 2632 & 1750 & 1588 \\
2009 & 4350 & 3546 & 2234 & 1750 & 2116 \\
2010 & 4800 & 4473 & 2818 & 2400 & 1982 \\
2011 & 5600 & 4567 & 2877 & 3200 & 2723 \\
2012 & 5300 & 3762 & 2370 & 2800 & 2930 \\
2013 & 5500 & 4400 & 2772 & 2800 & 2728 \\
2014 & 5400 & 4500 & 2835 & 2600 & 2565 \\
2015 & 5200 & 4300 & 2709 & 2100 & 2491 \\
2016 & 5000 & 4286 & 2700 & 2000 & 2300 \\
\hline
\end{tabular}

Source: USDA, 2016.

In the last four decades, small-scale mills have been very active; representing more than $60-70 \%$ of Nigeria's total milling capacity and producing at a milling rate of 55-60\%. However, their final products tend to be of lower quality because of limited equipment (USDA, 2016). Poor quality of locally milled rice has been identified as one of the major reasons for high import volume, as consumers prefer imported rice to local rice (Adeyeye et al., 2010; Johnson et al., 2013). To reverse this situation, the government and private sector have since 2010 invested a total of over \$1.7Billion in the establishment of more than 43 medium to large scale modern integrated rice mills (IRMs) (Anchors) with a total milling capacity of over 2.3 million metric tons per annum (Tables 2 and 3). Locally milled rice brands being produced by IRMs have been found to be comparable to imported rice brands in terms of high quality and packaging such that consumers are indifferent between local and imported rice on the basis of physical quality attributes (Alfred and Adekayode, 2014). Previous consumer-preference studies have shown that there is still an overall acknowledgement of higher organoleptic attributes such as taste, aroma and freshness which consumers prefer in favour local rice, but it is not the most decisive attribute in many cases ((Lançon et al., 2003; Tetteh et al., 2011; Demont et al., 2012). This implies that consumers' purchase of IRM-milled rice brands is based mostly on their availability and price. But, there are evidences that more than $70 \%$ of the IRMs are operating below $30 \%$ capacity due to the inadequate domestic supply of paddy (USDA, 2016).

Table 2: List of Functioning Integrated Rice Mills (IRMS) (Anchors) in Nigeria

\begin{tabular}{llll}
\hline S/N & Name and Location & $\begin{array}{c}\text { Capacity } \\
\text { (tons/annum) }\end{array}$ & $\begin{array}{c}\text { Investment Level } \\
\text { (\$US million) }\end{array}$ \\
\hline 1 & Onyx Rice Mills Bida, Niger State & 12,000 & $\mathrm{NA}$ \\
2 & Olam Nigeria Ltd, Doma LGA, Nasarawa State & 105,000 & 120 \\
3 & JICA/FMARD/Nasarawa State ADP Incubation Rice Mill, Lafia & 4,000 & 0.8 \\
4 & Conti Agro (Eko Rice Mill), Imota, Ikorodu, Lagos & 13,200 & 5 \\
5 & Popular Foods Ltd, Lagos & 210,000 & 22.5 \\
6 & Popular Foods and Mills Ltd, Kano & 150,000 & 23.4 \\
7 & Mikap Nigeria Ltd, Makurdi & 60,000 & 5 \\
8 & Al Umalau Nigeria Enterprise Ltd Jaling, Taraba State & 9,000 & 3.5 \\
9 & Quarra Rice Mill, Tsaragi, Kwara State & 24,000 & $\mathrm{NA}$ \\
10 & Gouria Rice Mill Ltd, Bauchi & 5,000 & 0.75 \\
11 & Danmodi Food Processing Nig. Ltd, Jigawa State & 12,000 & 1 \\
12 & Umza Rice Mill, Kano & 75,000 & 10 \\
13 & Tara Agro Industry Ltd, Adani, Enugu State & 42,000 & 12 \\
14 & Integrated Grains Processor Nig. Ltd, Enugu & 12,000 & 0.5 \\
\hline
\end{tabular}




\begin{tabular}{llll}
\hline 15 & Stine Industries Ltd, Amichi, Anambra State & 132,000 & 40 \\
16 & Ebony Agro Industry Ltd, Ebonyi State & 30,000 & 7 \\
17 & Modern Rice Mill, Ikwo, Ebonyi State & 12,000 & NA \\
18 & Modern Rice Mill, Iboko, Ebonyi State & 12,000 & NA \\
19 & Modern Rice Mill, Oso-Edda, Ebonyi State & 12,000 & NA \\
20 & Labana Rice Mill, Kebbi State & 100,000 & 36 \\
& TOTAL & $\mathbf{1 , 0 3 1 , 2 0 0}$ & $\mathbf{2 8 7 . 6}$ \\
\hline
\end{tabular}

Source: CARD, 2015.

Note: IRMs with a capacity of less than 3,000 tons per annum were not included the Table 2.

Domestic paddy production in Nigeria is dominated by smallholder farmers (SHFs) who cultivate 1-2 hectares of farmland but account for more than $80 \%$ of the total paddy rice production, while large-scale commercial farms with mechanization account for only less than $10 \%$ of cultivated areas and less than $20 \%$ of total production (FFI, 2016; GrowAfrica, n.d.). There are various programmes the government initiated in the past such as the Agricultural Credit Guarantee Scheme (ACGS), Rural Financing (RUFIN), etc. aimed at assisting SHFs access credit from the formal sector. However, these programmes have not made expected impact in increasing farm output due to unwillingness of financial institutions in Nigeria especially the DMBs to fully participate (Adegbite, 2009). DMBs perceive lending to SHFs as high risk because their farming business is unstructured due to poor functioning of value chains (Augustine et al., 2013), relatively long gestation, seasonal and exposed to unpredictable weather conditions (Philip et al., 2009; IFC, 2012). The transaction cost of lending to SHF is high because individual loan amount is often small due low volume of business, and when cooperatives are involved, the SHFs are often many, residing in remote rural locations, and are distantly dispersed thereby making monitoring by DMBs more difficult (Okello, 2012). In addition to the high risk and transaction costs, SHFs cannot afford the type of collateral acceptable to DMBs to secure any credit extended to them (Okojie et al., 2010). These explain the reasons why in the last 10 years, DMB's lending to agriculture as a percentage of total lending in the economy has been below $5 \%$ (CBN, 2017).

Table 3: List of Newly Completed or Expanded Integrated Rice Mills

\begin{tabular}{llll}
\hline S/N & Name and Location & $\begin{array}{l}\text { Installed } \\
\text { Capacity } \\
\text { (MT/Annum) }\end{array}$ & $\begin{array}{l}\text { Investment } \\
\text { Level } \\
\text { (\$million) }\end{array}$ \\
\hline 1 & & 52,000 & 3.4 \\
2 & Klysat Foods \& Beverage Ltd, Hadejia, Jigawa State & 30,000 & 10 \\
3 & 3-Brothers Rice Mill, Hadeja, Jigawa State & 70,000 & 2.2 \\
4 & Masco Agro Allied Ind. Ltd, Makurdi, Benue & 190,000 & 57 \\
5 & Masco Agro Allied Ind. Ltd, Makurdi, Benue (Expansion Planned) & 360,000 & 108 \\
6 & Popular Farms \& Mills Ltd, Kano Expansion Planned & 52,800 & 30 \\
7 & 2nd Line Conti Agro (Eko Rice Mill), Lagos Expansion Planned & NA & 1,000 \\
8 & Dangote Rice Mills & 144,000 & 53 \\
9 & Pearl Universal Impex Ltd, Bida, Niger State & 75,000 & 35 \\
10 & Elephant Group Ltd/Veetee Rice Mill, Ofada Ogun State. & 36,000 & 10 \\
11 & FMARD Approved Rice Mill Allocated to Elephant Group Ltd, Niger State & 54,000 & 55 \\
12 & Elephant Grp Ltd Rice Mill (Product of Satake of Netherland), In Kebbi State. & 100,000 & 20 \\
13 & Wacot Rice Mill, Lailaba Arugungu, Kebbi State & 30,000 & 9.3 \\
& Pemo Farms Ltd, Aviele, Auchi LGA, Edo State & $\mathbf{1 , 1 9 3 , 8 0 0}$ & $\mathbf{1 , 3 9 3}$ \\
\hline
\end{tabular}

Source: CARD, 2015

Studies have confirmed that smallholders' access to credit increases farm production efficiency and productivity leading to an increased output, income and food security (Reyes et al., 2012; Nouman et al., 2013). To boost domestic paddy rice production, the Nigerian government launched the anchor borrowers' programme (ABP) in November 2015. ABP is designed to provide cheap and partially-secured loans to smallholder farmers (SHFs). This is to make lending attractive to DMBs and agricultural loans accessible and cheaper to SHFs. Despite the importance of ABP in supporting smallholder farmers to access credit, empirical evidence arising from field experiences, which would guide agricultural policy makers and development practitioners in their efforts to fine-tune the ABP guidelines to make the programme more successful and sustainable, is still sparse. 


\section{Objectives of the Study and Research Methodology}

The main objective of this paper is to help SHFs, who are an important segment of Nigeria's population, to benefit from opportunities offered by the ABP. Specifically, this paper aims at: Assessing the impact of ABP in boosting paddy rice production in Nigeria; Describing the challenges threatening the success and sustainability of ABP; Identifying strategic policies for enhancing the effectiveness of ABP guidelines through the functional synergies of all the participants in the programme. This study was conducted in 2017 through purposive sampling of the rice millers (Anchors) and DMBs who participated in the 2015/2016 and 2016/2017 ABP across the major rice producing States in Nigeria, including Kebbi, Benue, Kaduna, Niger, Taraba, Enugu, Cross River and Ebonyi. Primary data collection was through focus group discussion with farmers' aggregators, DMBs, and rice millers (anchors) who participated in the programme in 2015/2016 and 2016/2017 rice farming season. Data were collected by the participatory approach in which representatives of Anchors and DMBs shared their field experiences on the challenges, opportunities, prospects and the lessons learnt against the existing provisions of ABP guidelines. Secondary data, including the ABP guidelines, was obtained from the Development Finance Department of the Central Bank of Nigeria (CBN). In addition, secondary data were obtained from the United States Department of Agriculture (USDA) and Coalition for African Rice Development (CARD). Data were analysed using descriptive statistics.

An Overview of the Anchor Borrowers' Programme (ABP) Model in Nigeria: The Central Bank of Nigeria (CBN) in line with its developmental function established the Anchor Borrowers' Programme (ABP) to create a linkage between anchor companies involved in the processing and smallholder farmers (SHFs) of the required key agricultural commodities especially rice, wheat and sugar. ABP is funded with the N220 billion Micro, Small and Medium Enterprises Development Fund (MSMEDF) of CBN through the deposit money banks (DMBs) at a cost of $2 \%$ and maximum interest rate of $9 \%$ to SHFs and tenor equivalent to be the gestation period of the identified commodities (CBN, 2016). The implementation of ABP is primarily supervised by the development finance office (DFO) in the Development Finance Department (DFD) of CBN in the various States across Nigeria. The main thrust of ABP is to provide conditions that make it attractive for DMBs to lend to SHFs. This involves ensuring: (1) cheaper credit; (2) timely and reliable supplies of farm inputs; (3) improved the capacity of SHFs through training on modern farming methods and practices; (4) guaranteed market for farm produce; and (5) provision of partial-collateral. The ABP model helps to structure the agricultural value chain to minimize the credit risk DMBs face when lending to SHFs. ABP is targeted at boosting production of key agro-enterprise (wheat, sugar, rice, maize, fish, cotton, etc.), stabilize inputs supplies to SHFs and agro-processors (Anchors) and address the country's negative balance of payments on food. At harvest, the SHF supplies his/her produce to the agro-processor (Anchor) who pays the cash equivalent to the farmer's account.

Objectives of ABP: According to CBN (2016), the broad objective of the ABP is to create an economic linkage between smallholder farmers and reputable large-scale processors with a view to increasing agricultural output and significantly improving capacity utilization of processors. Other objectives include: Increase banks' financing to the agricultural sector. Reduce agricultural commodity importation and conserve external reserves. Increase capacity utilization of agricultural firms creates a new generation of farmers/entrepreneurs and employment deepen the cashless policy and financial inclusion. Reduce the level of poverty among smallholder farmers assist rural smallholder farmers to grow from subsistence to commercial production levels.

Implementation of ABP Model: The implementation of $\mathrm{ABP}$ is coordinated by a project management Team (PMT) comprising of the representative of all the stakeholders including the Central Bank of Nigeria (CBN), Deposit Money Banks (DMBs), representatives of smallholder farmers (SHFs), Agricultural Development Programme (ADP), Nigeria Agricultural Insurance Corporation (NAIC) under the chairmanship of the CBN representative (Head of Development finance officer, DFO). The implementation of the ABP is a collective responsibility of all the stakeholders involved. The ABP guideline prepared by CBN has clearly spelt out the various infractions and sanctions (CBN, 2016). Figure 1 shows the process flow of implementation activities under the ABP model. It was difficult for DMBs to conduct KYC (know-your-customer) and due diligence of the SHFs as the authenticity, accuracy and reliability of their bio and farm data, as submitted by their respective anchors, associations, ADPs, etc., could not be verified. This led to the emergence of many part- 
time farmers who took advantage of the cheap ADP funding and the credit risk guarantee provided under the ABP. It was observed that majority of these set of part-time farmers had limited time attending to their field crops.

Figure 1: Anchor Borrowers' Program (ABP) Process Flow Chart

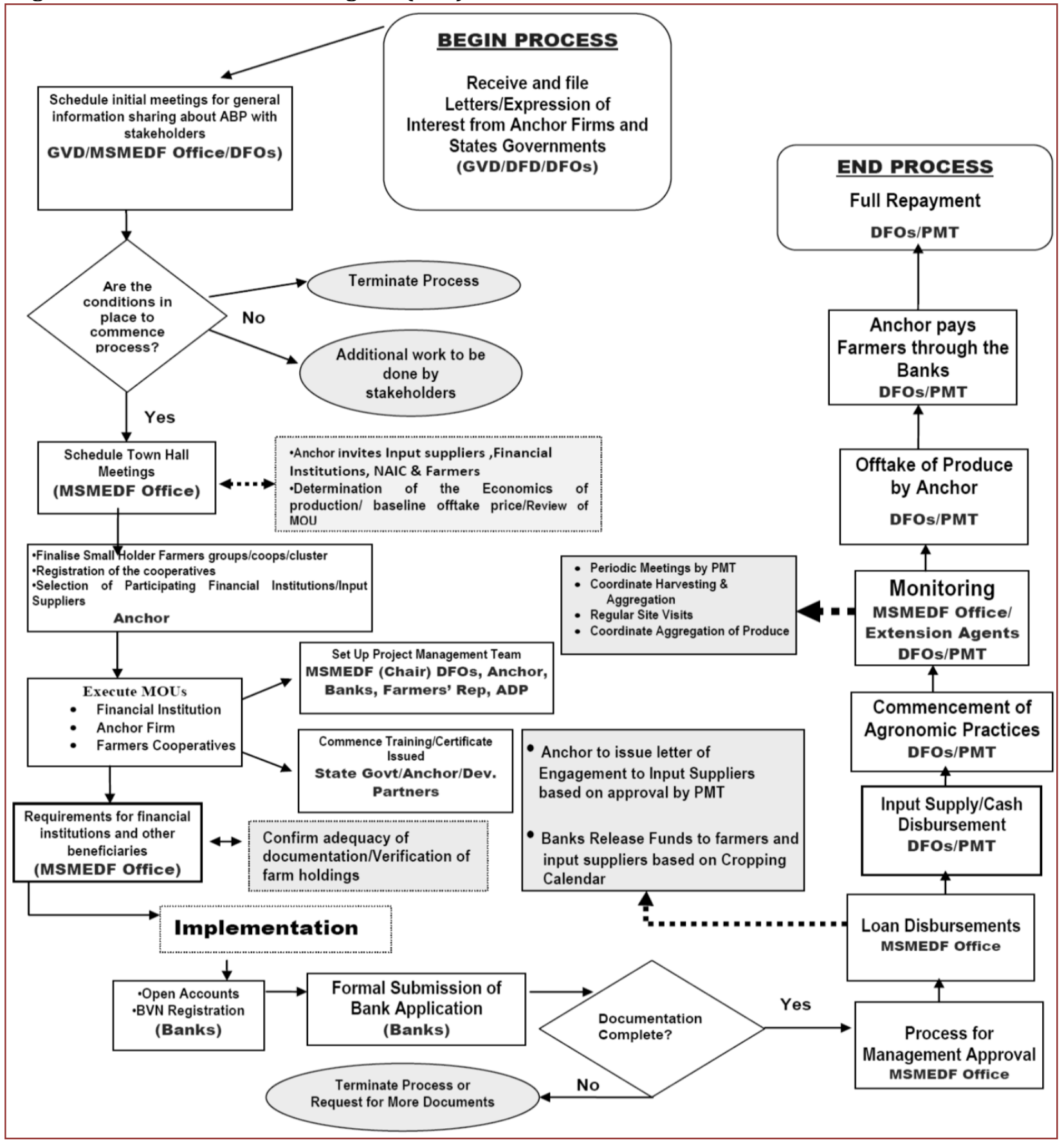

Source: CBN (2016)

SHF Eligibility and Acceptable Collaterals: Smallholder farmers (SHF) must be a registered member of a recognized cooperative group who holds between 1-5 hectares of farmland and can provide at least $5 \%$ of the loan amount he/she requires. Such a farmer is issued a certificate after undergoing mandatory training covering farming as a business, improved agricultural practices and group management dynamics. 
Certificates issued at the end of the training constitute a requirement for farmers to access credit facility inkind and cash under the ABP. The cost of such training is borne by the participating anchor and/or State government. According to the ABP guideline (CBN, 2016), funds disbursed by DMBs under the ABP are secured by: (a) tripartite agreement signed by SHFs, DMBs and Anchor; (b) cross and several guarantees by farmers in cooperatives registered on the National Collateral Registry (NCR); (c) SHFs' equity contribution of at least $5 \%$ of loan amount; (d) CBN credit risk guarantee (CRG) of 50\%; and NAIC insurance cover.

Risks and Mitigating Measures: The various risks envisaged in the ABP as well as the measures put in place to mitigate such risks have been outlined in Table 4.

Table 4: Risks and Mitigants in ABP

\begin{tabular}{ll}
\hline Risks & Mitigants \\
\hline Poor farming techniques/low crop yield & Comprehensive farmer education/technical assistance \\
Credit officers not skilled in agric financing & Value chain finance training for bankers \\
Effective monitoring of the process/project & PMT comprising all stakeholders will be put in place \\
Farmers have no stake in the programme & Equity contribution of 5\% - 10\% in place \\
No market for products & Off-takers in place with MOUs executed \\
Price variation & Guaranteed minimum Price by FMARD in place \\
Loss of crops due to natural incidences & NAIC Agric Insurance is compulsory \\
Poor quality/fake inputs leading to low yields & PMT selects recognised agro-dealers \\
Diversion of funds by farmers & Direct disbursement to agro-dealers \\
Default by farmers/Side selling & SHFs are to be selected by the miller. Cross and joint \\
& guarantees by all members of the cooperative. Miller approves \\
& all disbursement requests by farmers. Use of extension \\
\hline & workers \\
\hline
\end{tabular}

Source: CBN, 2016

\section{Results and Discussion}

Impact of ABP Funding on Boosting Nigeria's Rice Output: ABP was launched by the Federal Government on $17^{\text {th }}$ November 2015 in Kebbi State, North-west Nigeria. About 70,000 farmers benefitted from the pilot phase (2015/2016 dry season farming). According to a report by the CBN, as at February 2017, about \#29billion (\$US83million*) had been disbursed to over 125,963 smallholder farmers (SHFs) in 10 States who cultivated a total of 160,083 hectares at an average of 1.2 hectares per farmer through 31 anchors (CBN, 2017). This implies that the ABP has so far added about 1,207,090 tons of paddy rice into the economy. There are additional 24 States that have submitted an expression of interest to CBN to key into the programme for $2017 / 2018$ rice farming season. Under the ABP, the average productivity has increased from 3.5 tons per hectare to 5 tons per hectare because of quality inputs and best agronomic practices (CBN, 2017). This indicates a tremendous improvement in the average yield of paddy rice in Nigeria under the ABP given that previous statistics have shown a yield of between 1.5 to 3 tons per hectare (Johnson et al., 2013). Studies support the hypothesis that access to credit increases the productivity and profit of smallholder farmers (Hazarika and Alwang; 2003; Foltz, 2004).

Table 5: Performance of ABP in 2015/2016 Dry Season and 2016 Wet Season for Rice

\begin{tabular}{lll}
\hline & $\mathbf{2 0 1 5 / 2 0 1 6}$ Dry season & 2016 Wet season \\
\hline No of SHF beneficiaries & 73,941 & 125,963 \\
No of hectares & 81,335 & 160,083 \\
No of Anchors & 2 & 31 \\
Total output of paddy & 406,675 & 800,415 \\
\hline
\end{tabular}

Source: CBN, 2017

${ }^{*}$ \$US1 $=$ N350 
Key Challenges Threatening the Success and Sustainability of ABP in Nigeria: DMBs' long checklist of documentary requirements; complex bureaucracy in loan processing; and SHFs' inability to make 5\% equity contributions were found to be the major sources of delays in timely disbursement of funds by DMBs. Previous studies have confirmed that these factors hinder SHFs' access to credit and repayment capacity (Okorie, 1986; Agnet, 2004; Nmadu et al., 2013). Inadequate personnel and institutional arrangements were found to have hampered the effective implementation of ABP at the rural level such as selection of farmers, verification of farms, effective monitoring, supervision and reporting of farm activities. This finding is supported Evbuomwan and Okoye (2017), who found a dearth of extension agents as one of the implementation challenges of ABP in Nigeria. This contributed to inefficient coordination of logistics among the key participants and implementers of the programme including the PMT, DMBs, and Anchors leading to late supply/distribution of inputs to farmers, extension services provision and aggregation and supply of harvested paddy rice to anchors.

Had more challenges in repaying the loans and constituted the largest percentage of SHFs who defaulted in loan repayment and recovery by DMBs. Coker et al. (2018) observed a lack of updated database as one of the major issues militating against the effective implementation of the ABP. Side-selling of harvested farm produce by SHFs was one of the major challenges found to be a threat to the success of ABP. The guideline of ABP clearly stipulated that SHFs should sell their harvested farm produce to the Anchor in line with the executed tripartite memorandum of understanding (MOU). Majority of the SHFs gave various reason for sideselling, which included: (1) settlement of debt from other lenders due to late disbursement of ABP funds; (2) obtaining higher market prices being offered by Anchors that were not participating in the ABP; (3) withholding of sales at the harvest period in order to take advantage of increased market price during the offseason; and (4) expression of their dissatisfaction for non-receipt of ABP fund on time. Previous studies identified other reasons for side-selling such as government interference, weak institutional linkages, lack of trust among the value chain actors (SHFs, Anchors, DMBs, etc.), poverty, etc. (Coker et al., 2018; Evbuomwan and Okoye, 2017; Grow Africa, n.d.).

It is mandatory for SHFs to take up insurance cover for their field crops. There were several incidences of farm destructions by flood, drought, fire and nomadic herdsmen. The insurance cover provided by Nigeria Agricultural Insurance Company (NAIC) does not protect field crops against grazing. Besides, there was a poor channel of communication which made it difficult for farmers to report to NAIC within 24 hours as required. Hence, farmers experienced some difficulties in getting insurance compensation from NAIC. State government participated in the mainstream of ABP programme by providing the equity contribution and extension services for SHFs as stipulated in the ABP guideline. However, it was observed that government involvement in the programme created a wrong impression to SHFs who see the loan as a grant from the government. This confirms the findings of previous studies that many SHFs were insensitive, resolute and unresponsive in repaying loans because the majority of the SHFs erroneously believed that the loan is from the government.

Hence, a grant that is not supposed to be repaid (Oladeebo, 2008; CBN, 2005; Ben-Yami, n.d.). This attitude of SHFs largely contributed to the low repayment of ABP loans. Most smallholder farms are in remote rural areas of Nigeria where infrastructure such as good roads, bridges, telecommunication, etc. and security are grossly inadequate. These contribute to hamper the Anchors and DMBs in moving cash for on-farm payments to SHFs who often preferred and insisted on cash receipt of payment for paddy rice sold to the Anchor. It was observed that high cost of transportation and the stress of travelling a long distance on bad roads discouraged the majority of these SHFs from going to the DMBs in the urban areas to receive payments for paddy rice sold to the Anchor. This finding is corroborated by Bamiduro and Rotimi (2011) who observed that high cost of transportation was the major problem faced by SHFs in the marketing of their agricultural products in Nigeria.

Key Lessons from the 2015 - 2017 ABP: Field experience of DMBs indicated that farmers in the more remote rural areas easily repaid their loans more than those in the Urban and semi-urban areas. Farmers in urban and semi-urban areas were mostly civil servants who are already indebted to other lenders. There was higher loan recovery from farmers who owned just one hectare of farmland than those who owned more than one hectare. This agrees with the findings of Oke et al. (2007) and Kohansal and Manosoori (2009) who in 
their separate studies identified loan size as one of the factors that determine repayment. In addition, the majority of farmers who easily paid their $5 \%$ equity contribution had their loans easily repaid.

\section{Conclusion and Recommendations}

ABP is a laudable programme capable of boosting SHFs productivities and making Nigeria self-sufficient in rice production as it is specifically targeted at smallholder farmers (SHFs) who cultivate less than 5 hectares. Based on the challenges observed and key lessons learnt, the following recommendations are made to strengthen the ABP towards achieving its objectives. There is a need for a simplified and standardized procedure for processing loan request under the ABP. Given the remote residence location and literacy level of an average SHF, it is imperative for DMBs to design a single package loan application and appraisal form that must capture all the requirements expected from the SHFs such as MOU, cross guarantees, acceptance of the offer, etc. Also, DMBs need to develop and approve well in advance, an enterprise-specific product paper for financing rice farming under the ABP to avoid the long bureaucracy of obtaining approvals before the loan can be disbursed. This ensures timeliness in loan approval and disbursement.

There is a need for a well-articulated institutional framework to drive the ABP in the rural areas enhance extension services and provide real-time feedback to DMBs, NAIC, Anchor and CBN. An institutional framework for financing SHFs has been proposed for ABP (Appendix A). This framework will help to effectively synergize and integrate the roles of government agencies, DMBs, traditional institutions and agency banking in driving formal lending, financial inclusion banking and extension services delivery to SHFs in rural areas. It can provide a guide towards effective implementation of ABP model in Nigeria through a public-private-based partnership. As earlier observed by Augustine et al. (2013), a public-private-based partnership (PPP) linkage programme can effectively improve the functioning of agricultural value chains, and $\mathrm{ABP}$ is such a programme that can enhance the functioning of the rice value chain in Nigeria. DMBs need to work closely with Anchors who aggregate these SHFs for obtaining reliable data of their bios and farms for accurate KYCs and other information required for effective financial planning. There are several ways to stem side-selling by SHFs. Timely loan disbursement is key. There is a need to integrate into the ABP model, a robust mechanism and system of incentivising SHFs who sold to the Anchor. Loan repayment is automatic if the harvested paddy rice is sold to the Anchor. Transparency in the negotiation and agreement of selling price between the SHFs and Anchor is important Paglietti and Sabrie (2013).

Punitive measures and sanctions should be given to SHFs who default in loan repayment. These may include blacklisting of the farmers involved (using their BVNs), enforcement of loan recovery using the law enforcement agents, etc. There is a need for collaboration between CBN and DMBs to strengthen agency banking programme to facilitate payment of paddy in rural areas. The agency banking platform needs to be complemented with the establishment of paddy rice aggregation and procurement centres in rural areas where there are clusters of rice farmers. Each centre must be equipped with a weighing machine and the entire paddy harvested within the cluster farms are taken and weighed at the nearest procurement centre. NAIC insurance cover needs to be reviewed to include the destruction of farms by grazing animals. Other mechanisms such as farm residence, use of inedible plants for fencing, etc. need to be put in place for improved security of smallholder farms. There is a need for minimal involvement of State government in the ABP. The roles of the State government should be restricted to the provision of rural infrastructure (feeder roads, culverts, bridges, dams, etc.), security, extension services, and the establishment of a mobile court to try farmers who have defaulted in loan repayment. DMBs and Anchors need to develop an effective enlightenment programme to educate SHFs that the ABP loan is neither government largess nor a grant. CBN activities need to be restricted more to loan administration and supervision with minimal direct interactions with SHFs who often perceive ABP loans as a grant on sighting CBN staffs whom they perceive as government officials.

\section{References}

Adegbite, D. A. (2009). Repayment performance of beneficiaries of Ogun State Agricultural and Multipurpose Credit Agency (OSAMCA) in Ogun State (2004-2007). American-Eurasian Journal of Sustainable Agriculture, 3(1), 117-125. 
Adeyeye, J. A., Navesero, E. P., Ariyo, O. J. \& Adeyeye, S. A. (2010). Consumer preference for rice consumption in Nigeria. Journal of Humanities, Social Science and Creativity Arts, 5(1), 26-36.

Agnet. (2004). Making farm credit work for the small-scale farmers". http://www.agnet.org/library/nc/145b/ Accessed on February, 2017.

Alfred, S. D. Y. \& Adekayode, A. B. (2014). Consumers' attitude towards local rice production in Ondo State, Nigeria. Journal of Agricultural Extension and Rural Development, 6(7), 242-248.

Augustine, A., Jokthan, G., Zafari, I. \& Bivan, G. (2013). Optimizing opportunities for sustainable development through organic agriculture in Nigeria. IOSR Journal of Agriculture and Veterinary Science, 4(1), 7-11.

Ayanwale A. B. \& Amusan, C. A. (2012). Gender analysis of rice production efficiency in Osun State: Implication for the agricultural transformation agenda. Paper presented at the 13th National Conference of the Nigerian Association of Agricultural Economists Obafemi Owolowo University, Ile Ife, Nigeria, September 25 th $-27^{\text {th }}$

Bamiduro, J. A. \& Rotimi, A. G. (2011). Small-scale farming and agricultural product marketing for sustainable poverty alleviation in Nigeria. Open Journal System, 7(3), 56-63.

Ben-Yami, M. (n.d.). Integrated of traditional institutions and people's participation in an artisanal fisheries development project in south-eastern http//www.fao.org/DOCREP/004/Y1290/y1290e0e.htm Accessed on 17th February 2017

CARD. (2015). Private sector investment in the rice sector in response to government policies in Nigeria". Presentation at the $6^{\text {th }}$ general meeting of the coalition for African rice development (CARD), November 18-19, 2015 Accra, Ghana. https://riceforafrica.net/images/stories/PDF/S2-2EN.pdf Accessed on 17th February 2017

CBN. (2005). Microfinance policy, regulatory, and supervisory framework for Nigeria. http://www.cenbank.org/out/Publications/guidelines/dfd/2006/microfinance\%20policy.pdf Accessed $20^{\text {th }}$ February 2017

CBN. (2016). Anchor Borrowers' Programme Guidelines. Development Finance Department, Central Bank of Nigeria, Central Business District, Abuja.

https://www.cbn.gov.ng/Out/2017/DFD/Anchor\%20Borrowers\%20Programme\%20Guidelines\%20DEC\%20\%202016.pdf_Accessed $12^{\text {th }}$ February 2017

CBN. (2017). Anchor Borrowers' Programme (ABP). A report presented by ABP Unit of CBN during the meeting of CBN, Farmers and Anchors with the technical committee on food security held at CBN headquarters Abuja, Nigeria on $23^{\text {rd }}$ February 2017.

Coker, A. A., Akogun, E. O., Adebayo, C. O. \& Mohammed, U. S. (2018). Assessment of implementation modalities of the Anchor Borrowers' Programme in Nigeria. Agro-Science Journal of Tropical Agriculture, Food, Environment and Extension, 17(1), 44 - 52.

Demont, M., Rutsaert, P., Ndour, M., Verbeke, W., Seck, P. A. \& Tollens, E. (2012). Experimental auctions, collective induction and choice shift: willingness-to-pay for rice quality in Senegal. European Review of Agricultural Economics, 1-26.

Evbuomwan. \& Okoye. (2017). Evaluating the prospects of the anchor borrowers' programme for small-scale farmers in Nigeria. Paper presented at 21st International Farm Management Congress, John McIntyre Conference Centre, Edinburgh, Scotland, United Kingdom, 2-7 July 2017.

FAO. (2012). Food and Agriculture Organisation. Briefs on Import Surges - Countries No. 5 Ghana: rice, poultry and tomato paste.

FFI. (2016). http://ffinetwork.org/about/stay_informed/releases/images/Rice_Nigeria.pdf Accessed 20 ${ }^{\text {th }}$ February 2017

Foltz, J. D. (2004). Credit market access and profitability in Tunisian agriculture. Agricultural Economics, 30(3), 229-240.

GrowAfrica. (n.d). From smallholder to small business: private sector insights on service delivery models that boost profitability along the value chain. https://www.growafrica.com/resources/smallholder-smallbusiness-private-sector-insights-service-delivery-boosting-profitability Accessed 20 ${ }^{\text {th }}$ February, 2017

Hazarika, G. \& Alwang, J. (2003). Access to credit, plot size and cost inefficiency among smallholder tobacco cultivators in Malawi. Agricultural Economics, 29(1), 99-109.

IFC. (2012). Innovative Agricultural SME Finance Models". International Finance Corporation. November, 2012.

http://www.ifc.org/wps/wcm/connect/55301b804ebc5f379f86bf45b400a808/Innovative+Agricult ural+SME+Finance+Models.pdf?MOD=AJPERES Accessed 15 th January, 2017 
Isa, J. O., Cyprian, C. A. \& Sam, 0. O. (2012). Resource use efficiency and rice production in Guma Local Government Area of Benue State: An application of stochastic frontier production function. International Review of Social Sciences and Humanities, 3(1), 108-116.

Johnson, M., Takeshima, H., Gyimah-Brempong, K. \& Kuku-Shittu, O. (2013). Policy options for accelerated growth and competitiveness of the domestic rice economy in Nigeria". IFPRI policy note 35, IFPRI Washington, D.C.

Kohansal, M. R. \& Mansoori, H. (2009). Factors affecting on loan repayment performance of farmers in Khorasan-Razavi Province of Iran. Paper presented at the conference on International Research on Food Security, Natural Resource Management and Rural Development, University of Hamburg, October 6-8, 2009.

Lançon, F., Erenstein, O., Akande, S. O., Titilola, S. O., Akpokodje, G. \& Ogundele, O. O. (2003). Imported rice retailing and purchasing in Nigeria: A survey. West Africa Rice Development Association, Bouaké, Côte d'Ivoire.

Nmadu, J. N., Bako A. N. \& Baba K. M. (2013). Micro-credit requirement, acquisition and repayment by vegetable farmers in Nigeria. IJTEMT, 2(6).

Nouman, M., Siddiqi, M. F., Asim, S. M. \& Hussain, Z. (2013). Impact of socio-economic characteristics of farmers on access to agricultural credit. Sarhad Journal of Agriculture, 29(3), 469-476.

Ogunfowora, 0. (2007). Financial analysis of parboiling and milling technologies in the Kura-Kano corridor. PropCom Monograph Series 18.

Oke, J. T. O., Adeyemo, R. \& Agbonlahor, M. U. (2007). An empirical analysis of microcredit repayment in south-western Nigeria". Humanity and Social Science Journal, 2, 63-74.

Okello, J. J. (2012). Smallholder Agriculture: The Dilemma. Paper presented at FAO/UoNairobi Regional Workshop on Smallholder Commercialization held at Norfolk Hotel, Nairobi on June 6-7, 2012. http://www.fao.org/fileadmin/templates/esa/Workshop_reports/Smallholders_2012/Presentation s_1/Okello_Smallholder_Dilemma.pdf Accessed 12 th February, 2017

Okojie, C. A., Monye, E., Eghafona, E., Osaghae, G. \& Ehiakhamen, J. O. (2010). Institutional Environment and Access to Microfinance by Self - employed Women in the rural areas of Edo State. NSSP brief No. 14. Washington, D. C: International Food Policy Research Institute.

Okorie, A. (1986). Major determinants of agricultural smallholder loan repayment in a developing economy: Empirical evidence from Ondo State, Nigeria. Agricultural Administration, 21(4), 223-234.

Oladeebo, O. E. (2008). Determinants of loan repayment among smallholder farmers in Ogbomosho Agricultural Zone of Oyo State, Nigeria. Nigeria Journal of Social Science, 17(1), 59-62.

Opeyemi1, G., Adedeji, S. O., Komolafe, S. E., Arotiba, K. \& Ifabiyi, J. O. (2015). Analysis of consumers' preference in patronizing locally produced and imported rice in Niger state, Nigeria. Nigerian Journal of Agriculture, Food and Environment, 11(3), 38-43.

Paglietti, L. \& Sabrie, R. (2013). Linkages for inclusive agribusiness development. A report prepared under the FAO/World Bank Cooperative Programme, FAO Rome, 2013. http://www.fao.org/docrep/019/i3404e/i3404e.pdf Accessed 20th February 2017

Phillip, D., Nkonya, E., Pender, J. \& Oni, O. A. (2009). Constraints to increasing agricultural productivity in Nigeria: A review. Nigeria Strategy Support Program (NSSP) Background Paper No. NSSP 006.

Reyes, A., Lensink, R., Kuyvenhoven, A. \& Moll, H. (2012). Impact of Access to Credit on Farm Productivity of Fruit and Vegetable Growers in Chile. Paper presented at the International Association of Agricultural Economists (IAAE) Triennial Conference, Foz do Iguaçu, Brazil, 18-24 August 2012.

Tetteh, B. A., Sidney, N. A. \& Stanislaus, A. A. (2011). Consumer preferences for rice quality characteristics and the effects on price in the Tamale Metropolis, Northern Region, Ghana. International Journal of Agricultural Science, 1(2), 67-74.

USDA. (2016). United States Department of Agriculture (USDA). Global Agricultural Information Network (GAIN) report. USDA Foreign Agricultural Services (FAS), April 2016.

https://gain.fas.usda.gov/Recent\%20GAIN\%20Publications/Grain\%20and\%20Feed\%20Annual_Lagos_Niger ia_4-21-2016.pdf Accessed 28 th February 2017. 


\section{Appendix A}

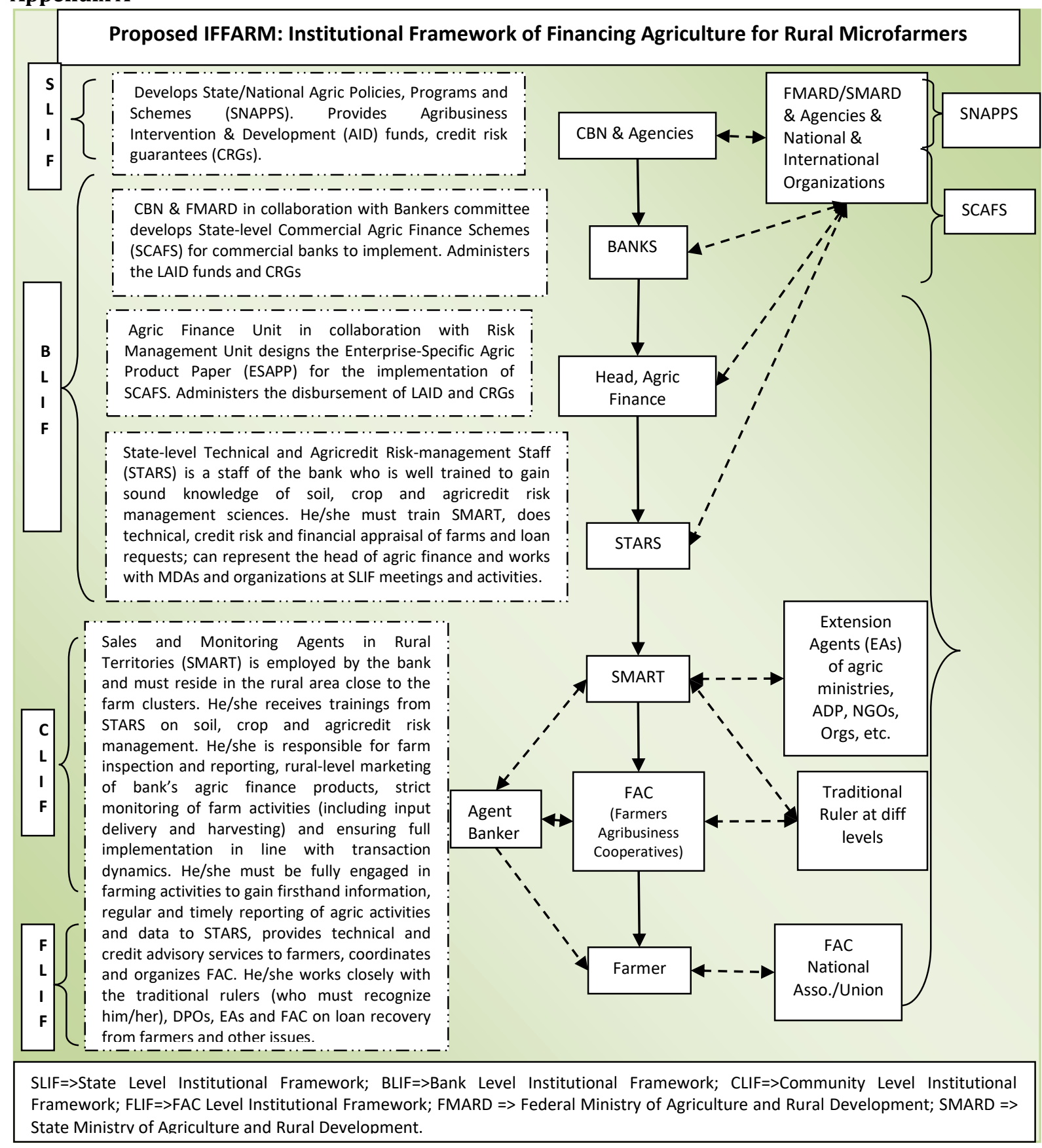

